\title{
Method, Development and Validation for the Estimation of Magnesium Content in Esomeprazole-magnesium by Atomic Absorption Spectrophotometer
}

\author{
BADITHALA. SIVA SAI KIRAN ${ }^{1 *}$ and SUNDARARAJAN. RAJA ${ }^{1}$ \\ 'GITAM Institute of Pharmacy, Gandhi Institute of Technology and Management (GITAM) \\ (Deemed to be University) Visakhapatnam, India. \\ ${ }^{*}$ Corresponding author E-mail: sivasaikiran143@gmail.com \\ http://dx.doi.org/10.13005/ojc/340155
}

(Received: September 12, 2017; Accepted: November 25, 2017)

\begin{abstract}
A simple, fast and efficient validated method is developed for determination of magnesium content in Esomeprazole-Magnesium by using atomic absorption spectrophotometer (AAS) with $0.2 \mathrm{~nm}$ slit width with high speed deuterium (D2) lamp. The read time was set at 3.0 second with $285.2 \mathrm{~nm}$ wavelength. The system performance was evaluated by performing the system suitability parameters. The limit of detection and limit of quantification were found to be $0.01 \mu \mathrm{g} / \mathrm{mL}$ and 0.03 $\mu \mathrm{g} / \mathrm{mL}$ respectively. The percentages of recovery for low, medium and high spiked concentration levels of magnesium in Esomeprazole-Magnesium were found to be 91.85, 95.02 and 97.89 respectively. With the developed method the magnesium content in Esomeprazole-Magnesium bulk sample was found to be $3.48 \%$ which compliance the United States Pharmacopoeia standard.
\end{abstract}

Keywords: Esomeprazole-Magnesium, Magnesium, AAS, Validation.

\section{INTRODUCTION}

Esomeprazole-Magnesium Trihydrate is an official drug in USP ${ }^{1}$ belongs to a category of proton pump inhibitor and is used in treating various acid related disorders ${ }^{2}$. Esomeprazole (Fig. 1), is a sisomer of omeprazole which is the first drug in its category developed as a single optical isomer ${ }^{3}$.
The literature review revealed that various analytical methods in single and combined dosage form involving spectrophotometer ${ }^{4-6}$, RP-HPLC ${ }^{7-14}$, HPTLC $^{15}$, UPLC ${ }^{16}$, LC-MS $^{17}$. Form the literature review it is found that there is no reported method for the estimation of magnesium in Esomeprazole-Magnesium as magnesium excess and lower levels in body will cause hyper

This is an Open Access article licensed under a Creative Commons Attribution-NonCommercial-ShareAlike 4.0 International License (https://creativecommons.org/licenses/by-nc-sa/4.0/), which permits unrestricted NonCommercial use, distribution and reproduction in any medium, provided the original work is properly cited. 


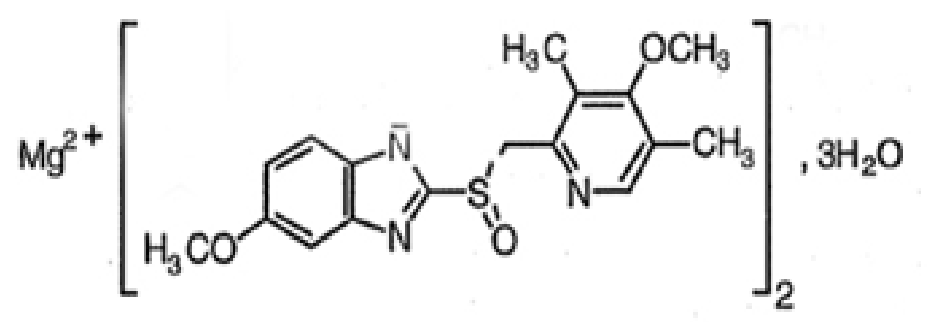

$\left(\mathrm{C}_{17} \mathrm{H}_{18} \mathrm{~N}_{3} \mathrm{O}_{3} \mathrm{~S}\right)_{2}, \mathrm{Mg} .3 \mathrm{H}_{2} \mathrm{O}$

Mol. Wt. 767.2

Fig. 1. Structure of Esomeprazole-Magnesium Trihydrate

magnesaemia and hypomagnesaemia. In the present study a validated method is developed by using AAS to determine magnesium content in Esomeprazole-Magnesium Trihydrate.

\section{MATERIALS AND METHODS}

\section{Reagents}

Esomeprazole-Magnesium is obtained as a gift sample from Varun herbals. Magnesium standard used in the study was purchased from Merck \& Co. Lanthanum chloride and hydrochloric acid of Sd fine chem were used and the water used is MilliQ water.

\section{Working Standards and Solutions Preparation Preparation of Lanthanum solution (4\%)}

Transfer $4 \mathrm{~g}$ of lanthanum chloride in to a $100 \mathrm{~mL}$ volumetric flask and add $50 \mathrm{~mL}$ of MilliQ water and dilute up to volume with MilliQ water.

\section{Magnesium Standard Stock Solution Preparation}

Pure $1000 \mu \mathrm{g} / \mathrm{mL}$ of magnesium standard was purchased from NIST Traceable Material which is considered as stock solution $A$.

Transfer $0.5 \mathrm{~mL}$ of above magnesium standard stock solution (1000 $\mu \mathrm{g} / \mathrm{mL}$ ) into a $20 \mathrm{~mL}$ volumetric flask and add $4 \mathrm{~mL}$ of $1 \mathrm{~N}$ hydrochloric acid and make up the volume with MilliQ water which is used as stock solution B. Transfer $0.1 \mathrm{~mL}, 0.2 \mathrm{~mL}$, $0.3 \mathrm{~mL}, 0.4 \mathrm{~mL}$ and $0.5 \mathrm{~mL}$ of above stock solution B $(25 \mu \mathrm{g} / \mathrm{mL})$ to a separate $25 \mathrm{~mL}$ volumetric flask add $1 \mathrm{~mL}$ of Lanthanum Chloride to each flask and dilute up to volume with MilliQ water i.e., $0.1 \mu \mathrm{g} / \mathrm{mL}$, $0.2 \mu \mathrm{g} / \mathrm{mL}, 0.3 \mu \mathrm{g} / \mathrm{mL}, 0.4 \mu \mathrm{g} / \mathrm{mL}$ and $0.5 \mu \mathrm{g} / \mathrm{mL}$ of
Magnesium respectively. From this solution a linear graph is plotted.

\section{Sample preparation}

Take $100 \mathrm{mg}$ of sample (EsomeprazoleMagnesium) to a clean and dry $100 \mathrm{ml}$ volumetric flask and add $20 \mathrm{ml}$ of $1 \mathrm{~N}$ hydrochloric acid and dilute up to volume with MilliQ water which is considered as a stock solution A. Allow the solution to stand for $30 \mathrm{~min}$. after that transfer $0.25 \mathrm{ml}$ of this solution to a $25 \mathrm{ml}$ volumetric flask and add $1 \mathrm{~mL}$ of lanthanum Chloride to each flask and dilute up to volume with MilliQ water.

\section{Preparation of Blank}

Transfer $1 \mathrm{~mL}$ of lanthanum chloride solution to a $25 \mathrm{~mL}$ volumetric flask dilute up to the mark with MilliQ water and mix.

\section{Instrumental Conditions}

An AA-6300 atomic absorption spectrometer equipped with fully integrated atomizers of Shimadzu Corp. make was used for the analysis. The system was operated from an interfaced computer running Wizard software. The following are the optimal operating conditions for flame atomization of Magnesium are presented in Table. 1

\section{RESULTS AND DISCUSSION}

\section{System Suitability}

System suitability is a measure to ensure the performance of the system. The results obtained for standard deviation of absorption values $(n=6)$ for magnesium working standards were presented in Table 2 and was within range of acceptance criteria (\%RSD $\leq 5)$. 
Table. 1: Optimal operating conditions for flame atomization of magnesium

\begin{tabular}{lc} 
Element & Magnesium \\
Wavelength & $285.2 \mathrm{~nm}$ \\
Read Time & $10 \mathrm{Sec}$ \\
Lamp Current & $12 \mathrm{MA}$ \\
Recommended Flame & Air-Acetylene \\
Fuel gas Flow & 2.0 \\
Support gas Flow & 17.0 \\
Slit Width & $0.2 \mathrm{~nm}$ \\
Signal type & Atomic Absorption \\
Atomization site & Burner Head \\
Equation & Linear through Zero \\
Flame Type & Air-Acetylene \\
Pre Spray time & $3 \mathrm{sec}$ \\
Integration time & $5 \mathrm{sec}$ \\
\hline
\end{tabular}

Table. 2: System Suitability

\begin{tabular}{lcc}
\hline S.No & $\begin{array}{c}\text { Magnesium } \\
\text { Concentration } \\
(\mu \mathrm{g} / \mathrm{mL})\end{array}$ & Absorbance \\
\hline 1 & 0.4 & 0.3390 \\
2 & 0.4 & 0.3397 \\
3 & 0.4 & 0.3428 \\
4 & 0.4 & 0.3458 \\
5 & 0.4 & 0.3475 \\
6 & 0.4 & 0.3453 \\
Average & 0.3434 & \\
SD & 0.0035 & \\
$\%$ RSD & 1.01 & \\
\hline
\end{tabular}

\section{Specificity}

Specificity is the ability to assess the analyte in sample with presents of unexpected other elements which interfere the results of analyte in sample. The results presented in Table. 3 .

Table. 3: Specificity

\begin{tabular}{lcc}
\hline $\begin{array}{l}\text { Magnesium } \\
\text { Concentration } \\
(\mathrm{ppm})\end{array}$ & Wavelength & $\begin{array}{c}\text { Average } \\
\text { Concentration } \\
(\mathrm{n}=6)\end{array}$ \\
\hline Blank Solution & 285.2 & 0.0020 \\
Standard Solution & 285.2 & 0.3532 \\
Sample Solution & 285.2 & 0.3582 \\
\hline
\end{tabular}

\section{Limit of Detection}

LOD is the lowest amount of analyte that can be detected which is determined by aspirating various concentrations with their respective absorbance shown in the Table 4. Flow the below table the LOD was found to be $0.01 \mu \mathrm{g} / \mathrm{mL}$

Table. 4: Limit of Detection

\begin{tabular}{lcc}
\hline S.No & Concentration & Absorbance \\
\hline 1 & $0.05 \mu \mathrm{g} / \mathrm{mL}$ & 0.0241 \\
2 & $0.04 \mu \mathrm{g} / \mathrm{mL}$ & 0.0213 \\
3 & $0.03 \mu \mathrm{g} / \mathrm{mL}$ & 0.0170 \\
4 & $0.02 \mu \mathrm{g} / \mathrm{mL}$ & 0.0088 \\
5 & $0.01 \mu \mathrm{g} / \mathrm{mL}$ & 0.0059 \\
6 & $0.005 \mu \mathrm{g} / \mathrm{mL}$ & -0.0466 \\
\hline
\end{tabular}

\section{Limit of Quantification}

LOD is the lowest amount of analyte that can be quantitatively determined with suitable precision and accuracy

$$
\begin{aligned}
\mathrm{LOQ} & =\mathrm{LOD} * 3.3 \\
& =0.01 * 3.3 \\
& =0.03 \mu \mathrm{g} / \mathrm{mL}
\end{aligned}
$$

\section{Precision at LOQ Level}

Precision reported as percentage relative standard deviation (\%RSD) by aspirating the 0.033 $\mu \mathrm{g} / \mathrm{mL}$ magnesium standard for 6 times. The results were presented in table 5 and were within range of acceptance criteria (\%RSD $\leq 5)$.

Table. 5: Precision at LOQ Level

\begin{tabular}{lcc}
\hline S.No & Concentration & Absorbance \\
\hline 1 & $0.033 \mu \mathrm{g} / \mathrm{mL}$ standard & 0.0166 \\
2 & $0.033 \mu \mathrm{g} / \mathrm{mL}$ standard & 0.0164 \\
3 & $0.033 \mu \mathrm{g} / \mathrm{mL}$ standard & 0.0165 \\
4 & $0.033 \mu \mathrm{g} / \mathrm{mL}$ standard & 0.0173 \\
5 & $0.033 \mu \mathrm{g} / \mathrm{mL}$ standard & 0.0177 \\
6 & $0.033 \mu \mathrm{g} / \mathrm{mL}$ standard & 0.0169 \\
Average & 0.0169 & \\
SD & 0.005 & \\
$\%$ RSD & 3.02 & \\
\hline
\end{tabular}

\section{Linearity \& Range}

The concentration of standard solution is directly related and proportional to absorption in their lower and upper limits. The calibration curve is shown in Fig. 2 and regression equation presented in Table. 6. 
The range was plotted between magnesium standard solution $0.03 \mu \mathrm{g} / \mathrm{mL}$ to 0.5 $\mu \mathrm{g} / \mathrm{mL}$ (The range plotted from LOQ level to $150 \%$ with respect to sample solution). The results were presented in Table 6 and were within range of acceptance criteria (Correlation Coefficient $\leq 0.99$ ).

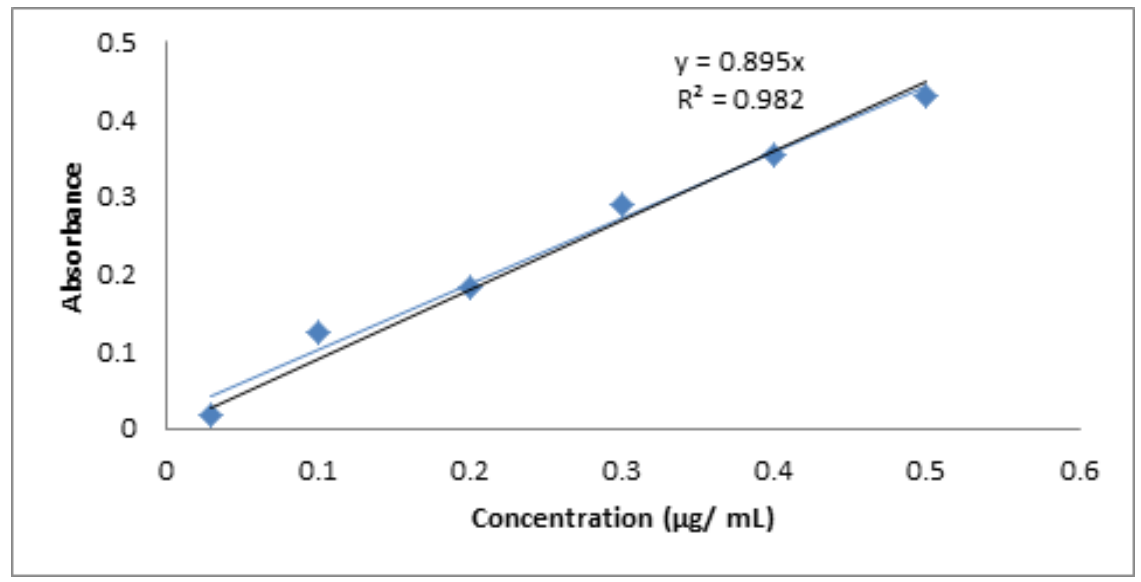

Fig. 2. Calibration Curve

Table. 6: Calibration Curve

\begin{tabular}{lc}
\hline Concentration $(\mu \mathrm{g} / \mathrm{mL})$ & Absorbance \\
\hline 0.0300 & 0.0165 \\
0.1 & 0.1253 \\
0.2 & 0.1818 \\
0.3 & 0.2892 \\
0.4 & 0.3537 \\
0.5 & 0.4309 \\
Correlation Coefficient & 0.9929 \\
\hline
\end{tabular}

\section{Accuracy/ Recovery}

Accuracy is the closeness of the test results obtained by the method to the true value which was obtained by spiking $50 \%, 100 \%$ and $150 \%$ of Esomeprazole-Magnesium working standard concentrations, in triplicates and accuracy/ recovery was shown in Table 7. The results were presented in table 7 and was within range of acceptance criteria (Accuracy/ \% Recovery in between $80 \%$ - 120\%) and the \%RSD for 3 spiked sample preparation should be NMT 5\%).

\section{Sample Analysis}

The sample was prepared and aspirated as per the above method and the Magnesium content (on anhydrous basis) found in the given sample is $3.48 \%$ which is within acceptance criteria (USP NF 40).

\section{CONCLUSION}

In the present study a validated simple, accurate, and precise method is developed to determine the content of magnesium in Esomeprazole-Magnesium bulk drug. The allowed magnesium content is present between $3.30 \%$ to $3.55 \%$ on anhydrous basis (USP NF 40). The sample which is analyzed by using the method developed is $3.48 \%$ so the magnesium content in the given sample is inacceptable range.

\section{REFERENCES}

1. United States Pharmacopeia NF 40.

2. Andersson, T.; Hassan-Alin, M.; Hasselgren, G.; Rohss, K.; Weidolf, L. Clin Pharmacol ., 2001, 40, 411-426.

3. Lind, T.; Rydberg, L.; Kyleback, A.; Jonsson, A.; Andersson, T.; Hasselgren, G.; Holmberg, J.; Rohss, K. Aliment Pharmacol.
Ther. 2000., 14,861867.

4. Patil, S. S.; Dhabale, P. N.; Kuchekar, B. Asian Journal of Research in Chemistry., 2009, 2 , 154-156.

5. Gawande, V. V.; Chandewar A. V.; International Journal of Pharmacy \& Technology., 2010, 2, 617-622. 
6. Prabu, S.L.; Shirwaikar, A.; Shirwaikar, A.; Kumar, C.D.; Joseph, A.; Kumar, R. Indian J Pharm Sci., 2008, 70, 128-31.

7. Dilip, G.; Maheshwari.; Trivedi, P. D. Int. J Appl Sci Eng., 2011, 9, 187-94.

8. Deepak Kumar, J.; Nitesh, J.; Rita, C.; Nilesh, J. Pharm Methods., 2011, 2, 167-72.

9. Imran, A.; Jat R.K.; Rambir, S.; Srivastava, V.; Srivatsava S. Int Res J Pharm., 2012, 3,111-113.

10. Zarna, D.; Ronak, D.; Vaishali, K.; Vidya Sagar, G.; Meeta, B.; Sheth, N. R. Asian J Research Chem., 2009, 2,108-111.

11. Meyyanathan, S.N.; Nagasamy Venkatesh, D.; Krishnaveni, N.; Babu, B.; Jeyaprakash, MR.; Rajanikanth, B. R. Int J Health Allied Sci., 2012, 1, 129-32
12. Onal, A.; Oztunç A. Journal of Food and Drug Analysis., 2006, 14, 12-18

13. Sripal Reddy, P.; Sait, S.; Vasudev murthy, G.; Vishwanath, B.; Prasad, V.; Jayapal Reddy, S. Der Pharma Chemica., 2011, 3, 553-564

14. Shetty, R.; Subramanian, G.; Kumar, R.A.; Pandey, S.; Udupa, N. Indian Drugs., 2005, 42, 158-161.

15. Sharma, S.; Sharma, M. C. AmericanEurasian Journal of Toxicological Science., 2011, 3,143-148.

16. Nalwade, S. U.; Reddy, V. R.; Rao, D.D.; Morisetti, N.K. J. Pharm. and Biomed., 2012, 57, 109-114.

17. Hultman, I.; Stenhoff, H.; Liljeblad, M. J Chromatography B., 2007, 848, 317-22. 